\title{
Commercialization of the Scientific Research Results in Iran Knowledge-Based Companies
}

\author{
Mansour Torkiantabar \\ PhD student of Information science and knowledge. Islamic Azad University, Science and Research branch, Tehran, Iran \\ Email: torkiantabar@yahoo.com
}

\section{Sedigheh Mohammad Ismaeil*}

Assistant professor of Information science and knowledge, Islamic Azad University, Science and Research branch, Tehran, Iran *Corresponding Author: m.esmaeili2@gmail.com

\section{Fatemeh Nooshinfard}

Assistant professor of Information science and Knowledge, Islamic Azad University, Science and Research branch, Tehran, Iran Email: f.nooshinfard@gmail.com

\section{Doi:10.5901/mjss.2016.v7n3s3p11}

\section{Abstract}

This research is conducted by purpose of determining awareness from the relationship between effective factors on commercialization results of scientific researches in Iran knowledge-based companies. The methodology of this research is descriptive-surveying in correlative form. To collect the needed data, researcher-made questionnaire has been used. Statistical population of this research consists 970 managers of knowledge-based companies that 275 of them were selected using Cochran formula. Research findings show the relationship among organizational, environmental-organizational, cultural-social, legal, and economic factors by commercialization of results of scientific researches in Iran knowledge-based companies; however, no relationship was seen in personal factors and commercialization.

Keywords: commercialization, scientific researches, knowledge-based companies, Iran

\section{Introduction}

Knowledge-based economic is an intangible economic structure by which knowledge is valuated as key factor in production. Economic growth in global advanced economics is based on knowledge incrementally besides which tangible assets such as capital and workforce are effective. Knowledge performance is creation so it can be functionalized for empirical analysis by innovation (Yeo, 2010).

In previous decade, innovation strategy in many membered countries of organization for economic co-operation and development (OECD) has focused on improvement of research results of "general science" institution and governmental research institutes. In Europe, this strategy focus to great extent is for Europe failure in utilization from its significant investment in general research in contrary, US experience believes on academic researches results. Another instrument of measuring success in US in commercialization the general science is significant income that universities such as Stanford, Columbia, MIT, and the University of Florida have earned from their patents (Arundel\& Bordoy, 2012).

Knowledge-based companies are research organizations which not only should research and develop new technologies, but also should provide proper conditions along with facilitating commercialization their research findings.

In these companies, capital is usually considered as risky capitals and professional organizations control them. Actually, they aim on specific merchandise market. Knowledge-based companies are made by knowledge economy and earn income by this way. Knowledge-based companies and institutes are private or different institutes which are established in order to synergize science and wealth, develop knowledge-based economy, accomplish economic and scientific purposes, and commercialize research and development results in prior fields with added-value particularly in producing related software (Cheng \& Liu, 2005).

According to World Economic Forum (ASVAB, 2010), national economic competitiveness is determined as "collection of institutions, policies, and actors which determine profitability of a state" (ASVAB, 2010). Clearly, competitive 
economies are usually able to make better consequences for their people (Filipović, Devjak \& Putnik). Knowledge-based discourse as obtained from formulated report of group of intellectuals in 1960s including futurists and information economists such as je loop (1963), Daniel Bell (1969), and Peter Rocker (1973) implying that industrial communities are changing to capitalist and industrial societies, and knowledge-based economics. Manuel Castells (1996) is one of significant writers who believed that knowledge is new basis and factor of production that is in conflict with this traditional deduction that earth (natural resources), work (human attempts), and capital goods (alternatives of instruments) are three main factors of production (Robertson, 2008).

On the other hand, findings of this research can have important role in evolution of societies economically and helps to increase social welfare of society members; however, these findings won't be important and compensate spending costs for research and producing science until get applied aspect and access to applicants. Low income countries face with many challenges to apply knowledge in their countries for lack of resources. (Santesso, 2006)

Commercialization results of scientific research in knowledge-based companies are a notion which has been emphasized in recent years. This notion roots from reality that development of these companies role on economic development and growth of county is undeniable. Negligence to role of knowledge-based companies, which are considered as the main key of economic growth, in today varied countries seeking for various policies for their economic development, result in irreparable damages the most important of which is non-using scientific capacities and consequently lag in global development and progress caravan.

Obstacles and problems such as economic, cultural, commercial, environmental, and organizational obstacles will be investigated in this research and relationship of each one with commercialization results of scientific research in knowledge-based companies will be analyzed and these are weakness and strength factors in the world countries and knowledge-based companies are not exceptional in them.

Knowledge in $21^{\text {th }}$ century (century with knowledge-based economy (KBE)) has changed into a vital product for countries, business, and people. Tangible documents show that knowledge and information are able to help people and nations to get to their developmental purposes. Developing countries, to invest in knowledge revolution for improvement, competitiveness, and welfare, should rely on their strength and plan precisely on investment on human capital, useful institutions, proper technologies, and competitive and thoughtful companies. (Kefela, 2010)

In $16^{\text {th }}$ century, Sir Francis bacon claimed that "knowledge is power" and provided new systems with target is producing scientific knowledge for human utilization. He considered this thought as business main idea in permanent and main changes and uncertainty. In these conditions, companies focus on their knowledge and development new knowledge more than ever in modern society. Knowledge is changing into a producing factor and consequently investment in research, development, and education which are proposed as thee principal economic policies. National economics and economic growth of a country depends on new knowledge amount and level. Effective and efficient knowledge application as the main factor to get to economic development objectives with traditional factors of products is undeniable necessities. Discussion about knowledge-based economy indicates a positive correlation between knowledge level of a country and its economic growth. (Kurtić \& Đonlagić, 2012)

Commercialization is a process in which results of scientific research or modern ideas including goods and services change and have financial benefit and usefulness. Commercialization is key for progress and development, because it provides condition for various countries to change their researchers' scientific results to the materials product and make economic growth and development possible. In spite of direct relationship of commercialization with economic growth and development, this fact shouldn't be forgotten that necessity of this effectiveness is conditions, facilities, proper condition for commercialization. In better words, economic growth and development is done favorably that each involved factors in commercialization is executed best.

Knowledge is key factor of organizational utilization and economic development of each country in dynamic competitiveness condition in global market. Demand to improve competitiveness condition needs to their knowledge resources so they could participate in global ranking to improve their condition. (Krstić, Stanišić, 2013)

Attention to science production as development policy has been always focused by the world and this increases in present condition. Competitiveness to participate in producing science and knowledge and going along with global evolutions and above all technological developments make countries attempts twice in this field. Science production is perquisite of scientific development and this wouldn't happen until this fact accomplishes.

Statistics shows that Iran has qualified status for producing science. Incremental and ascending growth of science production in country shows this reality that authorities, researchers, and experts have perceived importance of participation in global knowledge very well and have tried a lot to increase their country share, but it shouldn't be neglected that science production worthwhile when changes into good or services for all society members and also has benefit and profitability for global society. 
Knowledge-based economy in the first step depends on sing ideas instead of physical abilities and technology instead of delivery of raw materials or utilization from cheap workforce. It is economy in which knowledge is produced effectively by people, companies, and societies. Knowledge-based economy is changing needs and expectation of labor market in global economy. In industrial countries in which used knowledge in industry is increasing, labor market needs are changing in this regard. (World Bank, 2003)

Therefore, knowledge-based economy produces, promotes, and utilizes knowledge to accelerate economic development. A knowledge-based economy is which knowledge is the main production element as intellectual capital (Bedford, 2013). As it was said, knowledge-based economy is said to which foundation and basis is science and knowledge and functionalizing knowledge and science actually forms knowledge-based economy that is the most important reason for success using human force intellectual power.

Lin, Wang \& Kung (2015) in a research investigate commercialization inventions in Greek companies. Results of their researcher show that complementary assets and accessibility to obtained innovations from inventions influence on commercialization performance of invention positively and significantly.

Khayat (2015) in a research investigated effective factors on transferring technology in food industries of Philippine country. According to obtained results from this research, technology added-value, structural factors, related factors to transferring technology, related factors to government, and technological specification influence on technology transferring. Wang and Kung (2015) in a research under the title of "effect of reciprocal cooperation in commercialization the technology in Taiwan" concluded that reciprocal cooperation makes new opportunities to produce knowledge and technological commercialization, other results of this research indicate that producing knowledge has important role in technology commercialization performance directly about reciprocal interaction and technology commercialization performance. Krstić, Stanišić (2013) in a research investigated effect of knowledge-based economy on Southeast European countries. The purpose of this study is investigating effect of knowledge as vital resource of development in the mentioned countries competitiveness. Determining the relationship KEI and measured competitiveness level by Global competitiveness index $(\mathrm{GCl})$ in studied countries was the objective of tis research. Results of research showed the weak positive relationship between $\mathrm{GCl}$ and KEl. Terzmielak (2012) in a research examined commercialization the scientific research results and selling of the new efficient technology in Poland. Results of his research showed that business investment in R\&D is significantly less in Poland in comparison to international markets. High production speed of innovation and inventions don't necessarily means they are transferred to economy.

Nasiri and Kuhpayeh (2014) in a research examined knowledge commercialization in bio-pharmacological in Iran. Their research results showed that policy making, regulation, and management development are considered as effective factors in practical pattern $\mathrm{f}$ commercialization.

Fallahati (2013) in a research about knowledge-based companies in Kermanshah province concluded that according to experts, representatives, and managers view, Technology and Science Park knowledge-based companies of Kermanshah province intend to learning, teamwork skills, communicative skills, analytical skills, planning, and selling management as necessary skills for marketing of knowledge-based companies in Kermanshah Science and Technology Park. $(\mathrm{P}<0.01)$

In addition, strategic marketing and development of products are necessary abilities for marking of knowledgebased companies in Kermanshah Technologies and Science Park. $(P<0.01)$ Kiyarasi Heydar (2013) in his research under the title of "investigating potential commercialization knowledge in engineering and management of construction of Iran South Oil National Company" concluded that personal factors have determinant role in commercialization and interaction, management of spiritual ownership, senior managers, market, and customer-orientation are in the next ranks. (Kiyarasi Heydar, 2013). Kajian (2012) in a research under the title of "investigating success factors of knowledge-based companies in commercialization idea in market", which statistical population is established NB companies in Yazd Technologies and Scientific Park, concluded that idea testing in knowledge-based companies, conceptualization commercialization from idea, screening ideas, applied researching activities, movement toward market-orientation, and number of years and months passed on idea in knowledge-based companies are success factors in commercialization ideas in market.

Hassanpour Golafshani et al. (2011), in a research on effective factors on success in technology commercialization obtained from university research, studied the relationship among rare factors of Islamic Azad University, Aliabad Katul Branch. Results of this research indicated that all factors are directly and indirectly effective on technology commercialization in Islamic Azad University, Aliabad Katul Branch. Related factors to environmental conditions had the most effects on success of technology commercialization in university, then related factors to industry, technology transferring methods, and university were effective on success in commercialization, respectively.

Amin Mozaffari and Shamsi (2001) in a research investigated methods and approaches of commercialization of 
academic research. Results of their research showed that commercialization procedure has been ascending in examined years and it was indicated about identification relationships among performance variables and their effects on commercialization that there is significant relationship among variables of publishing articles in conferences, mutual research contracts, and post educational theses (MA/Sc) and commercialization. By investigating view of commercialization activators, it was indicated that they play role of relationship in industry offices in this principal process and know dynamic interaction with other units necessary to be successful. According to their point of view, commercialization methods have been mutual projects, consultation, issuing patents, and establishing commercial companies.

Results of the conducted studies show that commercialization the scientific studies have specific status in countries economics and in spite of challenges and obstacles in this way, innovation and science production are important commercialization instruments focused by countries more than ever. It means that challenges and problems in path of knowledge-based companies and other economical active companies are in a way that are not discerned easily and will have irreparable damages and harms for country.

\section{Methodology}

The method of this research is descriptive-surveying of correlative form. The researcher-made questionnaire was used to collect needed data. Statistical population of this study is 970 mangers of knowledge-based companies in metropolises such as Tehran, Tabriz, Shiraz, Isfahan, and Ahvaz that 275 people were selected among them as sample by the following formula:

\begin{tabular}{|c|c|}
\multicolumn{2}{c}{$n=\frac{N t^{2} \times p q}{N d^{2}+t^{2} p q}$} \\
\hline $\mathbf{N}=$ & 970 \\
\hline $\mathbf{t}=$ & 1.96 \\
\hline $\mathbf{d}=$ & 0.05 \\
\hline $\mathbf{p}=$ & 0.5 \\
\hline $\mathbf{q}=$ & 0.5 \\
\hline $\mathbf{n}=$ & 275.38 \\
\hline
\end{tabular}

Table (1): how to calculate sampling appropriate to volume

\begin{tabular}{|l|c|c|c|}
\hline City name & population volume & Sample \% & Definite sample volume \\
\hline Tehran & 592 & 61.03 & 168 \\
\hline Ahvaz & 35 & 3.61 & 1 \\
\hline Shiraz & 36 & 3.71 & 1 \\
\hline Mashhad & 87 & 8.97 & 25 \\
\hline Isfahan & 171 & 17.63 & 48 \\
\hline Tabriz & 49 & 5.05 & 14 \\
\hline Total & 970 & 100 & 275 \\
\hline
\end{tabular}

According to what is seen in table (1), 592 from 970 knowledge-based companies in Tehran, 35 in Ahvaz, 87 in Mashhad, 171 in Isfahan, and 49 in Tabriz were established. According to volume corresponding sampling, 168 knowledge-based companies in Tehran, 10 in Ahvaz, 10 in Shiraz, 25 in Mashhad, 48 in Isfahan, and 14 in Tabriz were selected as sample.

\section{Research Hypotheses}

1- There is significant relationship between personal factors and commercialization the results of scientific research.

2- There is significant relationship between organizational factors and commercialization the results of scientific research.

3- There is significant relationship between environmental-organizational factors and commercialization the results of scientific research.

4- There is significant relationship between cultural-social factors and commercialization the results of scientific research. 
5- There is significant relationship between legal factors and commercialization the results of scientific research.

6- There is significant relationship between economic factors and commercialization the results of scientific research.

\section{Research Conceptual Model}

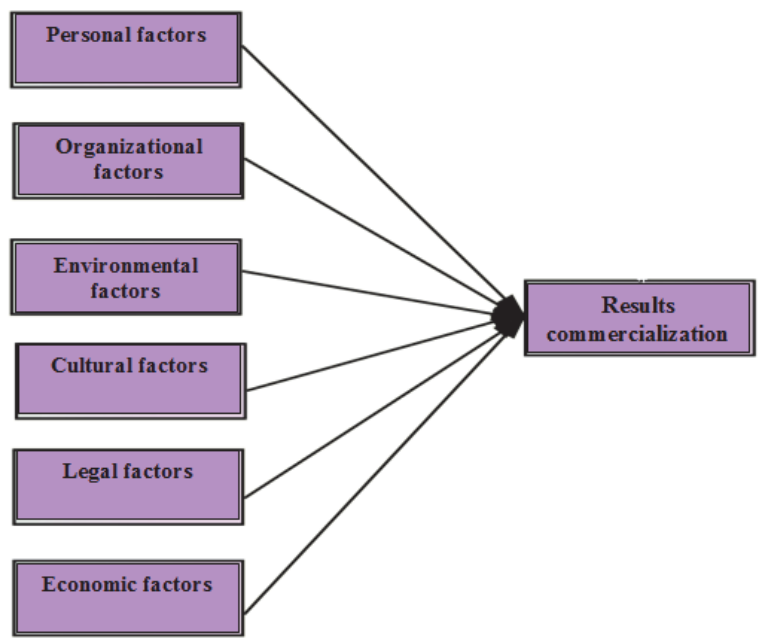

(Research Conceptual Model)

\section{Research Findings}

Table (2): frequency distribution of ownership type of knowledge-based companies

\begin{tabular}{|l|c|c|}
\hline Ownership type & Frequency & Frequency percentage \\
\hline Private & 163 & $59.3 \%$ \\
\hline Governmental & 69 & $25.1 \%$ \\
\hline Private-governmental & 43 & $15.6 \%$ \\
\hline Total & 275 & $100 \%$ \\
\hline
\end{tabular}

According to table (2), it is observed that $59.3 \%$ of knowledge-based companies in studied samples are in private ownership, $25.1 \%$ in governmental ownership, and $15.6 \%$ in private and governmental ownership.

Table (3): frequency distribution of title of knowledge-based companies

\begin{tabular}{|l|c|c|}
\hline Activity & Frequency & Frequency percentage \\
\hline Consulting & 79 & $28.7 \%$ \\
\hline Manufacturer & 83 & $30.2 \%$ \\
\hline Service provider & 16 & $5.8 \%$ \\
\hline Commercial & 30 & $10.9 \%$ \\
\hline Designing and engineering & 60 & $21.8 \%$ \\
\hline Others & 7 & $2.5 \%$ \\
\hline Total & 275 & $100 \%$ \\
\hline
\end{tabular}

As it is seen in table (3), the highest percentage of knowledge-based companies according to activity are manufacturer, consulting, designing and engineering, commercial, and finally service provider companies, respectively. 
Table (4): frequency distribution the cities of knowledge-based companies establishment

\begin{tabular}{|l|c|c|}
\hline City name & Frequency & Frequency percentage \\
\hline Tehran & 168 & $61.1 \%$ \\
\hline Ahvaz & 48 & $17.5 \%$ \\
\hline Shiraz & 10 & $3.6 \%$ \\
\hline Mashhad & 25 & $9.1 \%$ \\
\hline Isfahan & 10 & $3.6 \%$ \\
\hline Tabriz & 14 & $5.1 \%$ \\
\hline Total & 275 & 100 \\
\hline
\end{tabular}

As it is seen in table (4), the highest frequency of the sample companies was established in Tehran which means $62.2 \%$. Then in Isfahan with 17.5\%, Mashhad with 9.1\%, respectively with the highest frequency percentage.

Table (5): frequency distribution of establishment background of knowledge-based companies

\begin{tabular}{|l|c|c|}
\hline Establishment history & Frequency & Frequency percentage \\
\hline Fewer than 5 years & 135 & $49.1 \%$ \\
\hline 5-10 years & 82 & $29.8 \%$ \\
\hline $10-15$ years & 45 & $16.4 \%$ \\
\hline More than 15 years & 13 & $4.7 \%$ \\
\hline Total & 275 & $100 \%$ \\
\hline
\end{tabular}

As it is seen in table (5), $49.1 \%$ of knowledge-based companies have less than 5 years background, $29.8 \%$ have between $5-10$ years background, $16.4 \%$ of companies have $10-15$ years background, and finally $4.7 \%$ have more than 15 years background. Therefore, as it is seen, about $50 \%$ of companies have less than 5 years background and are at beginning of their activities.

\section{Hypotheses Test:}

Table (6): Pearson correlation coefficient between personal factors and commercialization results of scientific research

\begin{tabular}{|l|c|c|c|}
\hline \multirow{2}{*}{ Predictor variable } & \multicolumn{3}{|c|}{ Criterion variable } \\
\cline { 2 - 4 } & \multicolumn{3}{|c|}{ Commercialization results of scientific research } \\
\hline \multirow{2}{*}{ Personal factors } & Correlation & Sig. level & No. responders \\
\cline { 2 - 4 } & 0.017 & 0.776 & 275 \\
\hline Determination coefficient & \multicolumn{3}{|c|}{0.000} \\
\hline
\end{tabular}

As it is seen in table (6), result of data analysis show the significant relationship between personal factors and commercialization results of scientific research $(\mathrm{P}<0.01)$. It means $\mathrm{H}_{0}$ is confirmed in $95 \%$ and $\mathrm{H}_{1}$ is rejected.

Table (7): Pearson correlation coefficient between organizational factors and commercialization results of scientific research

\begin{tabular}{|l|c|c|c|}
\hline \multirow{2}{*}{ Predictor variable } & \multicolumn{3}{|c|}{ Criterion variable } \\
\cline { 2 - 4 } & \multicolumn{3}{|c|}{ Commercialization results of scientific research } \\
\hline \multirow{2}{*}{ organizational factors } & Correlation & Sig. level & No. responders \\
\cline { 2 - 4 } & 0.248 & 0.000 & 275 \\
\hline Determination coefficient & \multicolumn{3}{|c|}{0.061} \\
\hline
\end{tabular}

As it is seen in table (7), result of data analysis show the significant relationship between organizational factors and commercialization results of scientific research $(P<0.001)$. It means $H_{0}$ is rejected in $95 \%$ and $H_{1}$ is confirmed. Determination coefficient indicates that about $6 \%$ of variance of commercialization results of scientific factors is determined by organizational factor. 
Table (8): Pearson correlation coefficient between environmental- organizational factors and commercialization results of scientific research

\begin{tabular}{|l|c|c|c|}
\hline \multirow{2}{*}{ Predictor variable } & \multicolumn{3}{|c|}{ Criterion variable } \\
\cline { 2 - 4 } & \multicolumn{3}{|c|}{ Commercialization results of scientific research } \\
\hline \multirow{2}{*}{ Environmental- organizational factors } & Correlation & Sig. level & No. responders \\
\cline { 2 - 4 } & 0.280 & 0.000 & 275 \\
\hline Determination coefficient & \multicolumn{3}{|c|}{0.078} \\
\hline
\end{tabular}

As it is seen in table (8), result of data analysis show the significant relationship between environmental-organizational factors and commercialization results of scientific research $(\mathrm{P}<0.01)$. It means $\mathrm{H}_{0}$ is rejected in $95 \%$ and $\mathrm{H}_{1}$ is confirmed. Determination coefficient indicates that about $7 \%$ of variance of commercialization results of scientific factors is determined by environmental-organizational factor.

Table (9): Pearson correlation coefficient between cultural-social factors and commercialization results of scientific research

\begin{tabular}{|l|c|c|c|}
\hline \multirow{2}{*}{ Predictor variable } & \multicolumn{3}{|c|}{ Criterion variable } \\
\cline { 2 - 4 } & \multicolumn{3}{|c|}{ Commercialization results of scientific research } \\
\hline \multirow{2}{*}{ Cultural-social factors } & Correlation & Sig. level & No. responders \\
\cline { 2 - 4 } & 0.280 & 0.000 & 275 \\
\hline Determination coefficient & \multicolumn{3}{|c|}{0.078} \\
\hline
\end{tabular}

As it is seen in table (9), result of data analysis show the significant relationship between cultural-social factors and commercialization results of scientific research $(\mathrm{P}<0.01)$. It means $\mathrm{H}_{0}$ is rejected in $95 \%$ and $\mathrm{H}_{1}$ is confirmed. Determination coefficient indicates that about $10 \%$ of variance of commercialization results of scientific factors is determined by cultural-social factor.

Table (10): Pearson correlation coefficient between legal factors and commercialization results of scientific research

\begin{tabular}{|l|c|c|c|}
\hline \multirow{2}{*}{ Predictor variable } & \multicolumn{3}{|c|}{ Criterion variable } \\
\cline { 2 - 4 } & \multicolumn{3}{|c|}{ Commercialization results of scientific research } \\
\hline \multirow{2}{*}{ legal factors } & Correlation & Sig. level & No. responders \\
\cline { 2 - 4 } & 0.412 & 0.000 & 275 \\
\hline Determination coefficient & \multicolumn{3}{|c|}{0.169} \\
\hline
\end{tabular}

As it is seen in table (10), result of data analysis show the significant relationship between legal factors and commercialization results of scientific research $(\mathrm{P}<0.01)$. It means $\mathrm{H}_{0}$ is rejected in $95 \%$ and $\mathrm{H}_{1}$ is confirmed. Determination coefficient indicates that about $16 \%$ of variance of commercialization results of scientific factors is determined by legal factor.

Table (11): Pearson correlation coefficient between economic factors and commercialization results of scientific research

\begin{tabular}{|l|c|c|c|}
\hline \multirow{2}{*}{ Predictor variable } & \multicolumn{3}{|c|}{ Criterion variable } \\
\cline { 2 - 4 } & \multicolumn{3}{|c|}{ Commercialization results of scientific research } \\
\hline \multirow{2}{*}{ economic factors } & Correlation & Sig. level & No. responders \\
\cline { 2 - 4 } & 0.411 & 0.000 & 275 \\
\hline Determination coefficient & \multicolumn{3}{|c|}{0.0168} \\
\hline
\end{tabular}

As it is seen in table (11), result of data analysis show the significant relationship between economic factors and commercialization results of scientific research $(\mathrm{P}<0.01)$. It means $\mathrm{H}_{0}$ is rejected in $95 \%$ and $\mathrm{H}_{1}$ is confirmed. Determination coefficient indicates that about $16 \%$ of variance of commercialization results of scientific factors is determined by economic factor. 


\section{Discussion and Conclusion}

Commercialization process of results of scientific research in knowledge-based companies has been focused in recent years significantly. This emphasis is rooted from this reality that developments of these companies has undeniable effect in economic growth and development of their countries, in today world that all countries seek for various methods for their economic development, negligence to knowledge-based companies role, which are he main key vector of economic development, results in irreparable damages the most important of which is non-using scientific potentials and consequently lag of the world development and growth caravan. Utilization from scientific research results in knowledgebased companies is so noticeable that can have favorite effect on state economic growth and development and smooth sustainable development path.

Making conditions for commercialization research findings and providing knowledge to market and society besides providing significant economic values for research organizations, lead to technical and economic growth and increases society welfare. Importance of this issue made many studies about commercialization and providing to market the obtained products from the produced knowledge in various institutes.

Results of studies in state that some were mentioned in literature (Kiyarasi Heydar (2013), Nasiri Kuhpayeh (2014), Kajian (2012), Hassanpour Golfeshani (2012), Amin Mozaffari and Shamsi (2011)), cases such as personal factors, interaction, policy making, regulation, and management development, spiritual ownership, economic motivations, educational system, movement toward market-orientation, related factors to industry, technology transferring method, environmental factors, and so on have known effective on commercialization scientific results that results of the present research are agreed with them to the great extent. Results of Khayat (2015) research, Line, Wang and Kung (2015), England and Phillis (2012) as foreign studies also found similar results about relationship among structural factors, technology transferring, governmental factors, managerial issues with commercialization results of scientific results.

Results of this research indicate the positive and significant relationship among personal, organizational, environmental-organizational, cultural-social, legal, and economic actors and commercialization results of scientific research of knowledge-based companies. Although, such research is mostly related to results of academic research, a lot of similarities in commercialization the results of scientific research indicate that commercialization results of scientific research of country face with various challenges such as economic, legal, organizational, cultural and so on obstacles resulting in negligence, non-dynamisms, and economic dynamics.

Iran in developing country that evidences show it has taken long and valuable steps for economic growth and development and found significant success. Yet, it seems that attention to infrastructures and providing proper conditions and perquisites are necessary for this research to get to development superior purposes. Identification efficient and strong mangers, facilitation organizational processes, prevention from restrict regulations, provision environmental facilitations and equipment etc. are number of policies which can be considered regarding to results of this research to increase role and rank of knowledge-based companies in commercialization results of scientific research and consequently economic development of country.

\section{References}

Amin Mozaffari, Farugh, Shamisu, Loghman (2011), investigating commercialization methods, and approaches of academic studies, case study: Tabriz University. Science and technology journal, 15, 4-28

Hssanpour, Golafshani, Daryush; Gholami, Ramazan; Keshavarzi Shahram (2012). Investigating effective factors and their relationships on success of commercialization technology in Islamic Azad University, Aliabad Katul branch, national conference of entrepreneurship and knowledge-based business management, Mazandaran University, 23 (second fall month). 1-26

Kajian, Omid (2012). Investigating success factors of knowledge-based companies in commercialization idea in market (Yazd Technology and Science Park and satellite cities), MA/Sc thesis, Islamic Azad University, Arak branch

Arundel, Anthony g Bordoy, Catalina( 2012), Developing internationally comparable indicators for the commercialization of publiclyfunded research, United Nations University - Maastricht Economic and Social Research Institute on Innovation and Technology (MERIT).

Bedford, A. D. (2013). Expanding the Definition and Measurement of Knowledge Economy: Integrating Triple Bottom Line Factors into Knowledge Economy IndexModels and Methodologies. Journal of Modern Accounting and Auditing, 9(2), 278-286.

Falahati,A,et al(2013), Identifying and prioritizing capabilities and skills necessary for marketing knowledge-based companies of Science and Technology Park in Kermanshah, European online Journal of natural and social science,3:472-477.Filipović, Jovan, Devjak, Srečko, Putnik, Goran (2012), Knowledge Based Economy: The Role of Expert Diaspora, PANOECONOMICUS, and V.3

Lin,Y., Wang Y., Kung, L.A.,2015. Influences of cross-functional collaboration and knowledge creation on technology commercialization: Evidence from high-tech industries. Industrial Marketing Management Journal, 49:128-138.

Lin, J.H., Wang, M.Y., 2015. Complementary assets, appropriability, and patent commercialization: Market sensing capability as a 
moderator, Asia Pacific Management Review Journal, 4:1-7

Robertson, lan (2008), Learners' attitudes to wiki technology in problem based, blended learning for vocational teacher education, Australasian Journal of Educational Technology, 24(4), 425-441.

Nassiri-Koopae, Nasser,et al(2014), Commercialization of biopharmaceutical knowledge in Iran; challenges and solutions, DARU Journal of Pharmaceutical Sciences, open accsess:22-29.

Kefla, Ghirmai. T. (2010). Knowledge-Based Economy and Society Has Become a Vital,1:68-7

Khayat, Sami M (2015) Factors Affecting Technology Transfer in the Philippines Food Processing Industry. J Food Process Technol 6:441. doi: $10.4172 / 2157-7110.1000441$

Kiarasi Heidar, Pegah, Farahani Kangarani, Ali, Mehrabi, Javad(2013), Investigate the Potential Commercialization of Knowledge in Engineering and Construction Management of National Iranian South Oilfields Company, Journal of Basic and Applied Scientific Research,3:527-535.

Kurtic, Adil, Donlagic, Sabina (2012, Determining Key Factors for Knowledge Economy Development in Bosnia and Hercegovina, Management and Learning, International Conference, PP.421-413.

Krstic, B., Stanisic, T., 2013. The Influence of Knowledge Economy Development on Competitiveness of Southeastern Europe Countries, Industrija, 41:151-168

Santesso, Nancy, Tugwell, Peter (2006), Knowledge Translation in Developing Countries, The Journal of Continuing Education in the Health Professions, Volume 26, pp. 87-96.

Terzmielak, Dariusz, Kosiec, Jacek (2012), Commercialization on of technology - efficient sales of patents, licenses and results of research, minib: Marketing of Scientific and Research Organizations, the Scientific Journal by the institute of Aviation: 223:377395.

World Bank (2003b). ICT and MDGs: A World Bank Group Perspective. Washington, D.C., December.Yeo,Benjamin.J.K(2010),Driving the knowledge Economi: explaining the impact of Regional Innovation capacity on economic performance, Contemporary Management Research,V.6,pp.71-86 